\title{
Pembangunan Aplikasi Tracking Kecelakaan Lalu Lintas (Fast Help) Berbasis Mobile
}

\author{
Yance Sonatha $^{1^{*}}$, Ervan Asri $^{1}$, Indri Rahmayuni ${ }^{1}$, Yogi Febrian Wibawa ${ }^{1}$ \\ ${ }^{1}$ Jurusan Teknologi Informasi, Politeknik Negeri Padang \\ *Corresponding author, e-mail: yance@pnp.ac.id
}

\begin{abstract}
Abstrak - Kecelakaan lalu lintas merupakan masalah yang hampir terjadi di seluruh Negara di dunia ini. Masalah ini perlu penanganan serius untuk mencegah terjadinya kerugian dan korban yang lebih banyak. Penelitian ini mengembangkan aplikasi fast help yang mampu mengirimkan titik lokasi terjadinya kecelakaan pada pihak rumah sakit terdekat sehingga pertolongan terhadap korban dapat segera diberikan. Aplikasi ini dibangun dari dua sisi yakni server berbasis web dan client berbasis android. Aplikasi ini sudah diujikan pada beberapa titik lokasi di Kota Padang Sumatera Barat.
\end{abstract}

Kata Kunci : Android, Client Server, Kecelakaan Lalu Lintas, Sistem Tracking, Teknologi Mobile

\begin{abstract}
Traffic accidents are a problem that almost occurs in all countries in the world. This problem needs serious handling to prevent more losses and casualties. This research develops an application named "fast help" that is able to send the location of the accident to the nearest hospital so that assistance can be given to the victims immediately. This application is built from both sides, web-based server and Android-based client. This application has been tested at several locations in Padang City, West Sumatra.
\end{abstract}

Keywords : Android, Client Server, Traffic Accidents, Tracking System, Mobile Technology

\section{Pendahuluan}

Kecelakaan lalu lintas merupakan suatu peristiwa yang terjadi pada suatu pergerakan lalu lintas akibat adanya kesalahan pada sistem pembentuk lalu lintas yang melibatkan manusia sebagai pengemudi, kendaraan, jalan, dan lingkungan sekitar. Kecelakaan lalu lintas merupakan masalah yang hampir terjadi di seluruh negara di dunia ini, yang memerlukan penanganan serius mengingat besarnya kerugian yang diakibatkannya. Apabila masalah kecelakaan di jalan raya tidak diperhatikan dengan baik, dikhawatirkan akan terjadi peningkatan jumlah korban kecelakaan dari tahun ke tahun.

Berdasarkan data statistika jumlah kecelakaan lalu lintas meningkat tajam dalam 10 tahun terhitung 2007 sampai dengan 2016. Pada tahun 2007 tercatat terjadi 49.553 jumlah kecelakaan dengan total kerugian mencapai material mencapai 103 miliar rupiah. Sedangkan pada tahun 2016 jumlah kecelakan melonjak melebihi dua kali lipatnya yakni tercatat sebanyak 106.129 kejadian yang menimbulkan kerugian material mencapai hampir 227 miliar rupiah.[1]

Dari setiap kecelakaan lalu lintas, selain kerugian materi banyak juga menimbulkan korban jiwa baik itu meninggal, luka berat maupun luka ringan. Gambar 1 berikut ini memperlihatkan data statistika korban kecelakaan lalu lintas yang meliputi korban meninggal, luka berat maupun luka ringan dalam kurun waktu 10 tahun (2007 sampai dengan 2016). Dari gambar 1 tersebut dapat dilihat bahwa korban luka ringan meningkat drastic yakni tercatat sebanyak 46.827 jiwa pada tahun 2007 meningkat menjadi 121.550 jiwa pada tahun 2016. Sedangkan korban luka berat pada tahun 2007 tercatat sebanyak 20.181 jiwa dan jumlah ini meningkat menjadi 
22.558 jiwa pada tahun 2016. Data Biro Pusat Statistika ini juga mencatat terjadinya lonjakan jumlah korban ji wa (meninggal) pada kurun 10 tahun terakhir. Pada tahun 2007 tercatat sebanyak 16.955 jiwa meninggal kecelakaan dan jumlah ini meningkat menjadi 26.185 jiwa pada tahun 2016. Kebanyakan dari korban meninggal karena terlambatnya pertolongan dan penanganan terhadap korban.

Sementara itu teknologi informasi menjadi bagian tak terpisahkan dari masyarakat, terutama di kota-kota besar, tak terkecuali di Indonesia. Indonesia sedang dalam proses menuju masyarakat yang berorientasi digital.

Menurut penelitian Center of Innovation Policy and Governance (CIPG) yang dirilis pekan lalu, saat ini laju penetrasi internet Indonesia merupakan yang tertinggi di Asia yang kini sudah mencapai 51\%.

Angka yang lebih fenomenal terlihat dari jumlah pengguna seluler. Di tahun 2016, diprediksi ada sekitar 371,4 juta nomor seluler yang aktif di Indonesia. Jumlah tersebut bahkan lebih besar dari pada proyeksi jumlah penduduk Indonesia yakni 261,89 juta penduduk (142\% dari total populasi). Hal ini berarti bahwa rata-rata setiap penduduk memakai 1.4 telepon seluler karena satu orang terkadang menggunakan 2 sampai 3 kartu telepon seluler. [1]

Dari sejumlah pengguna telepon seluler tersebut, tercatat pada tahun 2017 terdapat 74,9 juta pengguna telepon pintar (smartphone) dan jumlah ini meningkat pada awal 2018 menjadi 83.5 juta. Jumlah pengguna ini diprediksi akan terus meningkat pada tahun 2019 dan diproyeksikan akan mencapai 92 juta pengguna.

Pesatnya laju penetrasi penggunaan teknologi informasi didukung juga oleh berkembangnya infrastruktur telekomunikasi, khususnya layanan data. Jika sepuluh tahun lalu jaringan yang tersedia belum melayani data dengan kecepatan tinggi, saat ini hampir seluruh wilayah Indonesia sudah terjangkau jaringan generasi ketiga $(3 \mathrm{G})$ maupun generasi keempat (4G).

Meningkatnya pembangunan infrastruktur jaringan mendorong masyarakat dapat dengan mudah mencoba berbagai aplikasi dan konten digital baru yang tersedia. Jika sebelumnya layanan telepon langsung dan pesan singkat (Short Messaging Service - SMS) banyak digunakan, saat ini layanan yang lebih banyak digunakan adalah aplikasi-aplikasi instant messaging, panggilan telepon melalui internet (Voice Over Internet Protocol VoIP), dan tentunya media sosial.

Tak hanya perkembangan teknologi dalam berkomunikasi, pergeseran masyarakat menjadi lebih melek teknologi juga dibarengi dengan adanya digitalisasi di berbagai bidang. Salah satunya di bidang teknologi. Aplikasi transportasi online seperti Gojek, Grab, maupun Uber menjadi salah satu aplikasi yang merupakan gaya hidup masyarakat perkotaan.

Ada pula perubahan dari segi jual-beli barang. Meskipun jumlahnya masih belum mayoritas, namun peminat perdagangan elektronik atau e-commerce terus meningkat. Tak hanya lewat situs-situs marketplace, namun media sosial seperti Facebook atau Instagram juga kerap digunakan masyarakat untuk bertransaksi.

Perubahan kebiasaan masyarakat juga terlihat dalam hal mendapatkan informasi sehari-hari. Dengan kehadiran perangkat bergerak/mobile, masyarakat menginginkan informasi lebih cepat dan akurat. Termasuk informasi peristiwa kecelakaan. Para pihak terkait dapat segera melakukan tindakan dan penanganan, apabila informasi kecelakaan lebih cepat diterima.

Dari permasalahan tersebut, maka perlu dikembangkan sebuah aplikasi yang memanfaatkan dan mengadopsi teknologi navigasi dari perangkat mobile untuk inmemberikan informasi segera terhadap peristiwa kecelakaan sehingga akan lebih cepat diberikan pertolongan. Model aplikasi ini nantinya diharapkan sebagai salah satu tools untuk meminimalisir jumlah korban kecelakaan lalu lintas.

\section{StUdi PUSTAKa}

\section{A. Android}

Android adalah sebuah sistem operasi untuk perangkat mobile berbasis linux yang mencakup sistem operasi middleware dan aplikasi. Android menyediakan platform 
terbuka bagi para pengembang untuk menciptakan sebuah aplikasi. Pada awalnya Google Inc. membeli Android Inc. yang merupakan pendatang baru yang membuat peranti lunak untuk ponsel/smartphone. Kemudian untuk mengembangkan Android, dibentuklah Open Handset Alliance, Konsorsium dari 34 perusahaan peranti keras, peranti lunak, dan telekomunikasi, termasuk Google, HTC, Intel, Motorola, Qualcomm, TMobile, dan Nvidia. [1]

\section{B. Android SDK (Software Development Kit)}

Android SDK adalah tools API (Application Programming Interface) yang diperlukan untuk mulai mengembangkan aplikasi pada platform Android menggunakan bahasa pemrograman Java. Saat ini disediakan Android SDK (Software Development Kit) sebagai alat bantu dan API untuk mulai mengembangkan aplikasi pada platform Android menggunakan bahasa pemrograman Java. [2]

Android SDK ini membantu proses pengembangan aplikasi android yang berisikan beragam libraries dan build tools yang dibutuhkan. Apabila menggunakan android studio sebagai lingkungan pengembangan aplikasi android, maka SDK ini telah disertakan dalam instalasi android studio tersebut. [3]

\section{Android Studio}

Android studio merupakan sebuah software tools Integrated Development Environment (IDE) untuk platform Android. Android studio diluncurkan pada tanggal 16 Mei 2013 pada Konferensi Google I/O oleh Produk Manajer Google, Ellie Powers. [4]

Didasarkan pada IntelliJ IDE, Android Studio menyediakan beberapa fitur tambahan dan pengembangan dari Eclipse ADT yang sebelumnya digunakan dalam pengembangan aplikasi Android. versi stabil pertama Android Studio dirilis pada Desember 2014 dan menjadi IDE resmi yang digunakan dalam pengembangan Android. [3]

\section{GPS (Global Positioning System)}

Global Positioning System atau GPS adalah sebuah alat atau sistem yang dapat memberikan informasi mengenai posisi keberadaan penggunanya. GPS bekerja berbasiskan satelit dan bersifat global, tidak terbatas ruang lingkup tertentu. Data dikirim dari satelit berupa sinyal radio dengan data digital. Satelit yang digunakan GPS milik Department of Defense Amerika Serikat yang pertama kali diperkenalkan tahun 1978 dan pada tahun 1994 sudah menggunakan 24 satelit (21 satelit bekerja aktif dan 3 sebagai cadangan).

Layanan GPS awalnya hanya digunakan untuk keperluan militer, tapi sejak tahun 1980 layanan ini dapat digunakan oleh publik. Layanan GPS sendiri dapat digunakan oleh semua orang secara gratis. Satelit yang digunakan mengorbit pada ketinggian sekitar 12.000 mil dari permukaan bumi. Ini dianggap sebagai posisi paling ideal karena satelit dapat menjangkau area coverage yang lebih luas. Maka semua satelit-satelit yang bekerja akan selalu berada di posisi yang dapat mencakup semua area di permukaan bumi. Ini bertujuan untuk meminimalkan adanya blank spot (area yang tidak terjangkau satelit). [5]

\section{E. GPS Tracking}

GPS Tracking adalah teknologi AVL (Automated Vehicle Locater) yang memungkinkan pengguna untuk melacak posisi kendaraan, armada ataupun mobil dalam keadaan real time. GPS Tracking memanfaatkan kombinasi teknologi GSM dan GPS untuk menentukan koordinat sebuah object, lalu menerjemahkannya dalam bentuk peta digital. [6]

\section{F. Google Maps API}

Google Maps API adalah salah satu Application Programming Interface (API) yang dimiliki Google. API ini mempunyai fitur untuk melakukan aktivitas-aktivias yang berkaitan dengan Google Maps, antara lain menampilkan peta, mencari rute terdekat antara dua tempat, dan lain sebagainya. Google Maps API tersedia untuk platform android, iOS, web, dan juga web service. 
Return value dari Google Maps Javascript API berupa string dengan format JSON yang berisi koordinat awal dan tujuan, rute, dan manuver. [7]

\section{G. Monitoring Menggunakan Google Maps API}

Monitoring merupakan suatu proses untuk mengumpulkan data dari berbagai sumber daya. Biasanya data yang dikumpulkan merupakan data yang real time. Secara garis besar tahapan dalam sebuah sistem monitoring terbagi ke dalam tiga proses, yaitu: [8]

1. Proses pengumpulan data monitoring

Data yang digunakan dalam melakukan monitoring adalah data dari hasil identifikasi lokasi, dimana data tersebut tersimpan dalam database berupa koordinat lokasi.

2. Proses analisis data monitoring

Data yang telah tersimpan dalam database akan dianalisis dan difilter sesuai dengan kebutuhan dalam melakukan monitoring.

3. Proses menampilkan data hasil monitoring Dalam menampilkan data hasil monitoring dapat memanfaatkan Google API, dimana produk ini menyediakan suatu API (Application Programming Interface) yang memungkinkan untuk menciptakan aplikasi yang sesuai dengan kebutuhan untuk menampilkan hasil dari monitoring. Google Maps API memberikan pengembang beberapa cara embedding Google Maps ke dalam aplikasi, dan memungkinkan baik untuk penggunaan sederhana atau customisasi yang luas. Hasil dari monitoring dapat divisualisasikan kedalam bentuk peta digital dari Google Maps sehingga dapat memudahkan user dalam melakukan monitoring.

\section{METODE}

Langkah-langkah yang dilakukan dalam penelitian aplikasi ini adalah:

1. Studi Literatur

Langkah ini bertujuan untuk mencari beberapa sumber tertulis yang berhubungan dengan aplikasi yang akan dibuat.
2. Rancangan

Pada perancangan sistem terdapat dua aplikasi yaitu aplikasi pelapor dan aplikasi rumah sakit. Gambaran umum rancangan sistem aplikasi fast help dapat dilihat pada Gambar 1 berikut ini :

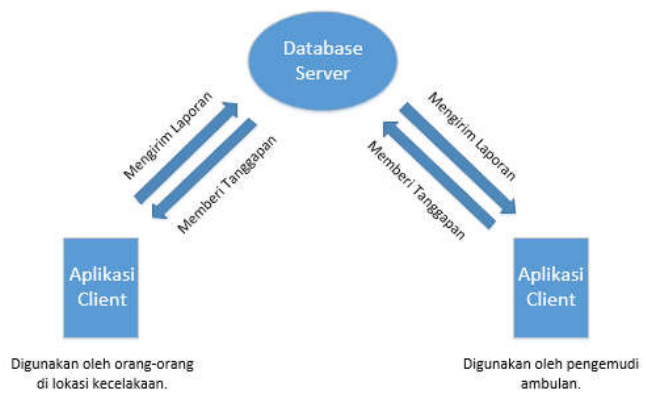

Gambar 1. Rancangan sistem aplikasi Fast Help

Aplikasi pelapor akan mengirimkan laporan kecelakaan berupa foto, keterangan, dan lokasi kecelakaan. Kemudian laporan akan sampai pada database server dan diteruskan ke aplikasi rumah sakit. Selanjutnya aplikasi rumah sakit akan memberikan tanggapan kepada si pelapor. Setelah itu, ambulan akan segera menuju lokasi kecelakaan yang didapat dari aplikasi pelapor. Dan dengan memanfaatkan fitur tracking pada aplikasi rumah sakit, ambulan bisa sampai pada lokasi kecelakaan dengan lebih cepat.

3. Pengujian

Langkah ini bertujuan untuk mengetahui alat yang dirancang sudah berjalan dengan baik.

4. Implementasi

Langkah ini merupakan langkah akhir dari pembuatan aplikasi ini setelah dilakukan pengujian.

\section{HASIL DAN PEMBAHASAN}

\section{A. Gambaran Umum Aplikasi}

Aplikasi Fast Help merupakan aplikasi yang digunakan untuk melaporkan kecelakaan kepada pihak rumah sakit sehingga pihak rumah sakit dapat mengirimkan ambulan ke lokasi kecelakaan guna memberikan pertolongan cepat kepada korban kecelakaan dengan adanya fitur tracking pada aplikasi Fast Help. 
Aplikasi ini terdiri dari dua aplikasi yaitu aplikasi pelapor dan aplikasi rumah sakit. Pada aplikasi pelapor terdapat menu lapor yang menampilkan form untuk menginputkan keterangan kecelakaan dan foto kecelakaan, ketika button lapor ditekan maka aplikasi akan mengirimkan data ke server beserta data tambahan yaitu lokasi kecelakaan. Pada aplikasi rumah sakit terdapat menu laporan yang menampilkan list laporan kecelakan yang sudah dikirim oleh pelapor. Ketika salah satu data pada list ditekan, maka aplikasi akan menampilkan data kecelakaan, dan apabila button maps ditekan, maka aplikasi akan menampilkan tracking dari lokasi rumah sakit ke lokasi kecelakaan.

\section{B. Perancangan Aplikasi}

Pada aplikasi Fast Help, bagian pelapor akan mendapatkan lokasi dari GPS pada saat pelapor mengirimkan data kecelakaan ke $W e b$ Server. Kemudian Web Server akan meneruskan data kecelakaan ke bagian rumah sakit, dan pada saat rumah sakit memberikan tanggapan kepada si pelapor, aplikasi rumah sakit juga akan mendapatkan lokasi dari GPS. Gambar 2 berikut merupakan blok diagram sistem dari aplikasi Fast Help.

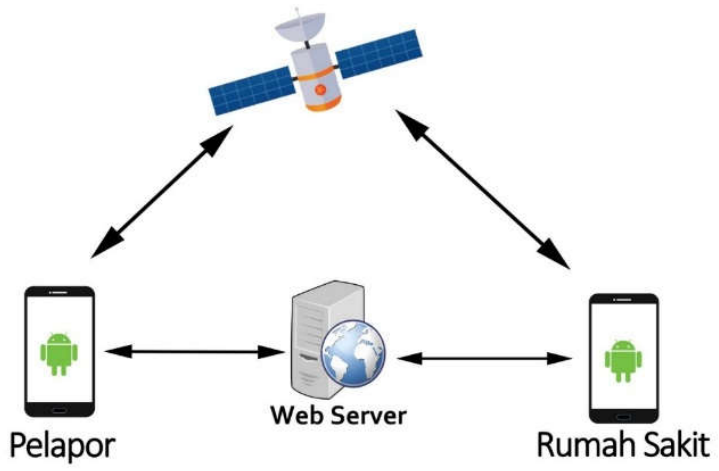

Gambar 2. Blok Diagram Aplikasi

C. Use Case Diagram

1. Use Case Diagram User Pelapor

Gambar 3 berikut merupakan use case diagram dari aplikasi pelapor yang mana terdapat seorang aktor yaitu pelapor sebagai penggerak sistem. Selanjutnya aktor tersebut dapat memilih menu pada navigation drawer yaitu menu lapor dan tentang aplikasi. Pada menu lapor, pelapor dapat menginput data kecelakaan dan melihat data kecelakaan yang sudah diinput. Lalu pada menu tentang aplikasi, pelapor dapat melihat penjelasan tentang aplikasi Fast Help.

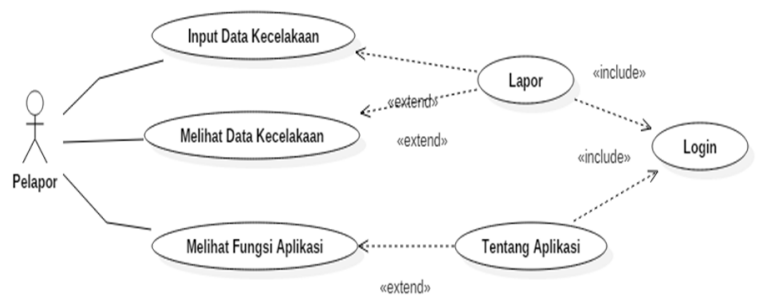

Gambar 3. Use Case Diagram User Pelapor

2. Use Case Diagram User Rumah Sakit Gambar 4 berikut merupakan use case diagram dari aplikasi rumah sakit yang mana terdapat seorang aktor yaitu operator rumah sakit sebagai penggerak sistem. Aktor tersebut dapat memilih menu pada navigation drawer yaitu menu laporan, history, dan tentang aplikasi. Pada menu laporan, operator rumah sakit dapat melihat list kecelakaan yang belum ditanggapi. Pada menu history, operator rumah sakit dapat melihat list kecelakaan yang sudah ditanggapi. Lalu pada menu tentang aplikasi, operator rumah sakit dapat melihat penjelasan tentang aplikasi Fast Help.

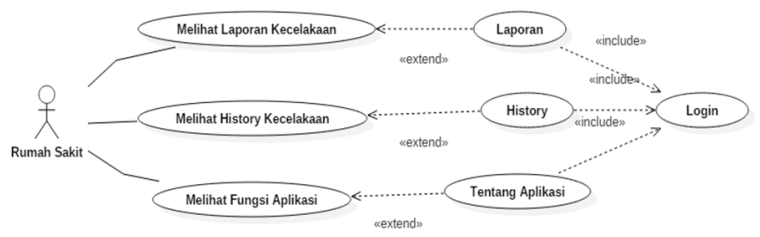

Gambar 4. Use Case Diagram User Rumah Sakit

\section{Implementasi dan Pengujian}

1. Tampilan user interface halaman login Pada saat aplikasi pertama kali dibuka, maka akan muncul tampilan halaman login. Tampilan halaman login dapat dilihat pada gambar 5 berikut. 


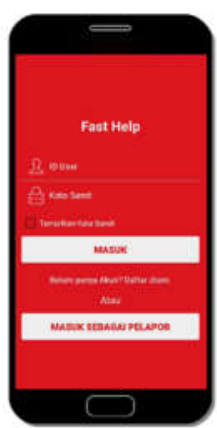

Gambar 5. Tampilan Halaman Login

Pada halaman ini user dapat masuk kedalam aplikasi sebagai pihak rumah sakit atau pelapor. Apabila user ingin masuk sebagai pihak rumah sakit, maka user harus menginputkan ID user dan password yang terdaftar pada database. Apabila user ingin masuk sebagai pelapor, maka user tidak perlu memasukkan ID user dan password.

2. Tampilan halaman registrasi

Pada saat user ingin mendaftarkan akun baru, maka akan muncul tampilan halaman registration. Tampilan halaman registration dapat dilihat pada gambar 6 . Pada halaman ini, user dapat melakukan pendaftaran akun baru dengan menginputkan beberapa data yang dibutuhkan

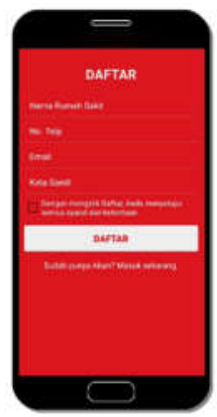

Gambar 6. Tampilan Halaman Registrasi

3. Tampilan halaman utama aplikasi pelapor Gambar 7 merupakan tampilan halaman utama aplikasi pelapor. Disini user dapat melihat list data kecelakaan yang sudah dilaporkan oleh masing-masing pelapor.

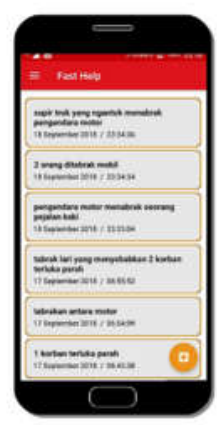

Gambar 7. Halaman Utama User Pelapor

Sedangkan gambar 8 berikut merupakan tampilan menu navigasi dari aplikasi pelapor. Pada menu navigasi ini terdapat tiga menu yaitu lapor, tentang aplikasi dan keluar. Menu lapor merupakan menu yang sama dengan halaman utama yang isinya list data kecelakaan. Menu tentang aplikasi merupakan menu yang menjelaskan info tentang aplikasi Fast Help. Dan menu keluar merupakan menu yang digunakan untuk logout user.

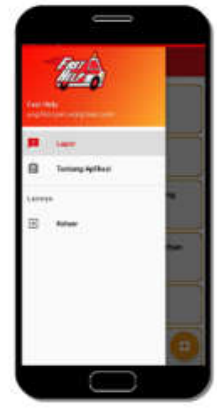

Gambar 8. Halaman Navigasi Pelapor

Pada halaman form input data kecelakaan seperti pada gambar 9, user harus menginputkan beberapa data yang dibutuhkan dari kecelakaan yang dilaporkan.

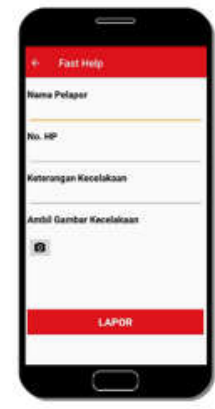

Gambar 9. Halaman Input Data Kecelakaan 
4. Tampilan halaman utama user rumah sakit Setelah user melakukan login sebagai pihak rumah sakit, maka aplikasi akan mengarahkan ke halaman utama aplikasi rumah sakit, seperti gambar 10 .

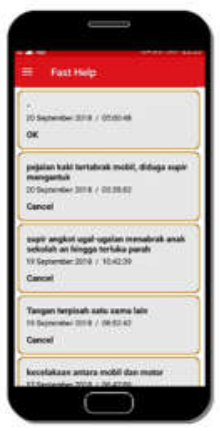

Gambar 10. Halaman Utama User Rumah Sakit

Pada halaman ini, user dapat melihat data kecelakaan yang sudah dilaporkan oleh pelapor yang belum ditanggapi. Pada list data kecelakaan pada menu navigasi user, apabila salah satu data ditekan, maka akan muncul detail dari data tersebut seperti terlihat pada gambar 11 .

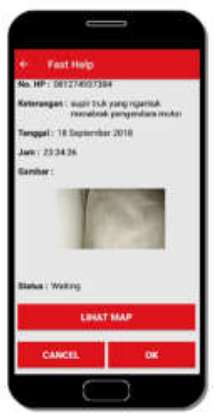

Gambar 11. Halaman Detail Kecelakaan

Pihak rumah sakit juga bisa melihat history data-data kecelakaan yang pernah ditanggapi oleh pihak rumah sakit tersebut seperti terlihat pada gambar 12 .

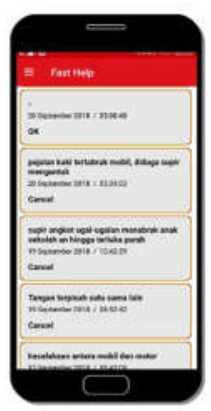

Gambar 12. Halaman Menu History

\section{KESIMPULAN}

Berikut ini beberapa kesimpulan yang dapat ditarik dalam pembuatan aplikasi Fast Help ini

Pada aplikasi pelapor, aplikasi ini dapat melaporkan kecelakaan kepada pihak rumah sakit dengan menginputkan beberapa data terkait kecelakaan yang ditemui.

Setelah pelapor menginputkan data, data akan muncul pada list data kecelakaan selama data belum ditanggapi oleh pihak rumah sakit. Setelah data ditanggapi oleh pihak rumah sakit, data akan hilang.

Pada aplikasi rumah sakit, aplikasi ini dapat menanggapi laporan yang diterima dari pelapor berdasarkan data yang diterima. Apabila data yang diterima adalah data kecelakaan yang sebenarnya, maka pihak rumah sakit dapat memilih OK dan langsung menuju lokasi kecelakaan. Apabila data yang diterima adalah data kecelakaan yang asalasalan, maka pihak rumah sakit dapat memilih Cancel dan mengabaikan laporan tersebut.

Pada aplikasi rumah sakit, data-data kecelakaan yang sudah ditanggapi akan pindah ke history.

Aplikasi Fast Help ini bisa dijalankan apabila smartphone terhubung dengan koneksi internet. Map pada aplikasi Fast Help ini belum bisa melakukan Direction karena dibutuhkan layanan Google Direction API dengan akun Google berbayar.

\section{DAFtar Pustaka}

[1] Biro Pusat Statistika, 2018

[2] Safaat, Nazruddin H. 2014. Android Pemrograman Apliaksi Mobile Smartpjone dan Tablet PC Berbasis Android. Bandung: Informatika Bandung.

[3] Hansun, Seng., Kristanda, Marcel Bonar., Saputra, Michael Wijaya. 2018. Pemrograman Android dengan Android Studio IDE. Yogyakarta: ANDI

[4] Yudhanto, Yudha., Wijayanto, Ardhi. 2017. Mudah Membuat dan Berbisnis Aplikasi Android dengan Android Studio. Jakarta: PT. Elex Media Kompurtindo

[5] Faiqunisa., Pratama, G. A. 2016. Monitoring Aktivitas Keluarga Berbasis GPS Tracking. Jurnal Teknologi Informasi dan Komunikasi, 5(1), 2-3

[6] Rachmat, N., Muhajirin, A., Mukhsin. 2015. Tracking Kendaraan Mobil Dengan 
Pemanfaatan GPS Berbasis Android. Jurnal Kajian Ilmiah UBJ, 15(2), 107

[7] Fikri, I. A., Herumurti, D., Rahman, R. 2016. Aplikasi Navigasi Berbasis Perangkat Bergerak dengan Menggunakan Platform Wikitude untuk Studi Kasus Lingkungan ITS. Jurnal Teknik ITS, 5(1), 2

[8] Afrizal., Sukmaaji, A., Sutanto, T. 2013. Android Personel Monitoring Location Pada Institusi Kepolisian Berbasis Web. Jurnal Sistem Informasi, 3(2), 22

[9] Noerkaisar, N., Suharjo, B., Yuliati, L.N. 2016.The Adoption Stages of Mobile Navigation Technology Waze App as Jakarta Traffic Jam Solution. Independent Journal of Management \& Production 7(3), 914-925

[10] Holla, S., Katti, M.M. 2012. Android Based Mobile Application Development and Its Security. International Journal of Computer Trends and Technology. 3(3), 486-490

\section{Biodata Penulis}

Yance Sonatha, adalah salah satu pengajar aktif di Jurusan Teknologi Informasi Politeknik Negeri Padang. Menamatkan kesarjanaan di Program Studi Ilmu Komputer FMIPA Universitas Gadjah
Mada tahun 2004 dan Magister Informatika di STEI Institut Teknologi Bandung.

Ervan Asri, menyelesaikan Sarjana Bidang Sistem Komputer di Universitas Putra Indonesia YPTK Padang pada tahun 2002 dan melanjutkan ke jenjang Magister Bidang Teknologi Informasi pada universitas yang sama dan lulus pada tahun 2005 . Sejak tahun 2008 tercatat sebagai pengajar di Jurusan Teknologi Informasi Politeknik Negeri Padang.

Indri Rahmayuni, menyelesaikan Sarjana Teknik pada tahun 2006 dari Institut Teknologi Bandung dan kemudian melanjutkan ke jenjang Magister Teknik ditempat yang sama dan lulus pada tahun 2011. Sejak tahun 2008 sudah tercatat aktif menjadi pengajar di Jurusan Teknologi Informasi Politeknik Negeri Padang

Yogi Febrian Wibawa adalah alumni Program Studi Teknik Komputer Jurusan Teknologi Informasi Politeknik Negeri Padang yang lulus pada Oktober 2018. 